\title{
IMPLEMENTASI ALGORITMA NAÏVE BAYES CLASSIFIER DAN SUPPORT VECTOR MACHINE PADA KLASIFIKASI SENTIMEN REVIEW LAYANAN TELEMEDICINE HALODOC
}

\author{
Reynalda Nabila Cikania ${ }^{1}$ \\ ${ }^{1}$ Departemen Statistika Bisnis, Fakultas Vokasi, Institut Teknologi Sepuluh Nopember
}

e-mail: reynalda.cikania@gmail.com

\begin{abstract}
Abstrak
Halodoc merupakan aplikasi layanan kesehatan berbasis telemedicine yang menghubungkan pasien dengan praktisi kesehatan seperti dokter, apotek, dan laboratorium. Ada beberapa komentar masyarakat pengguna aplikasi Halodoc, baik komentar yang bersifat positif maupun berisfat negatif. Hal ini menunjukkan adanya perhatian masyarakat terhadap aplikasi Halodoc sehingga perlu dilakukan analisis sentimen atau komentar yang muncul pada layanan aplikasi Halodoc terutama di masa pandemi COVID-19 agar layanan aplikasi Halodoc menjadi lebih baik. Algoritma Nä̈ve Bayes Classifier (NBC) dan Support Vector Machine (SVM) digunakan untuk menganalisis sentimen masyarakat pengguna aplikasi layanan telemedicine Halodoc. Hasil klasifikasi sentimen kategori negatif sebesar $12,33 \%$, sedangkan sentimen kategori positif adalah $87,67 \%$ dari 5.687 review yang artinya sentimen review positif lebih banyak daripada sentimen review negatif. Performa ketepatan klasifikasi Algoritma Naive Bayes Classifier menghasilkan tingkat akurasi sebesar 87,77\% dengan nilai AUC sebesar 57,11\% dan G-Mean sebesar 40,08\%, sedangkan Algoritma SVM dengan Kernel RBF memiliki nilai akurasi sebesar 86,1\% dengan nilai AUC sebesar 60,149\% dan nilai G-Mean sebesar 49,311\%. Berdasarkan nilai akurasi model dapat diketahui model SVM Kernel RBF lebih baik daripada NBC pada pengklasifikasian review sentimen pengguna layanan telemedicine Halodoc.
\end{abstract}

Kata Kunci: COVID - 19, Halodoc, Klasifikasi Naive Bayes, Support Vector Machine

\begin{abstract}
Halodoc is a telemedicine-based healthcare application that connects patients with health practitioners such as doctors, pharmacies, and laboratories. There are some comments from halodoc users, both positive and negative comments. This indicates the public's concern for the Halodoc application so it is necessary to analyze the sentiment or comments that appear on the Halodoc application service, especially during the COVID-19 pandemic in order for Halodoc application services to be better. The Nä̈ve Bayes Classifier (NBC) and Support Vector Machine (SVM) algorithms are used to analyze the public sentiment of Halodoc's telemedicine service application users. The negative category sentiment classification result was $12.33 \%$, while the positive category sentiment was $87.67 \%$ from 5,687 reviews which means that the positive review sentiment is more than the negative review sentiment. The accuracy performance of the Naive Bayes Classifier Algorithm resulted in an accuracy rate of $87.77 \%$ with an AUC value of $57.11 \%$ and a G-Mean of $40.08 \%$, while svm algorithm with KERNEL RBF had an accuracy value of $86.1 \%$ with an AUC value of $60.149 \%$ and a G-Mean value of $49.311 \%$. Based on the accuracy value of the model can be known SVM Kernel RBF model better than NBC on classifying the review of user sentiment of halodoc telemedicine service.
\end{abstract}

Keywords: COVID - 19, Halodoc, Nä̈ve Bayes Classifier, Support Vector Machine 


\section{PENDAHULUAN}

Telemedicine Halodoc adalah layanan kesehatan yang memanfaatkan teknologi informasi medis melalui media audio visual dan data dengan melibatkan beberapa pihak seperti dokter, pasien dan praktisi kesehatan lain secara jarak jauh (Coelho 2011). Aplikasi ini menyediakan berbagai fitur-fitur konsultasi medis melalui video call (teleconsultation), pemeriksaan lab secara on-demand, dan pembelian obat melalui apotek berbasis layanan online. Secara keseluruhan fitur-fitur yang ditawarkan telah mengikuti beberapa layanan yang ada di rumah sakit. Aplikasi Halodoc ini dapat diunduh dan diinstal melalui Google Play atau App Store.

Selama pandemi COVID-19 unduhan Halodoc meningkat 10 kali lipat pada dua bulan awal masa pandemi yaitu bulan Maret dan April 2020 (Fitri 2020). Peningkatan unduhan terjadi setelah Kementrian Kesehatan RI dan Badan Nasional Penanggulangan Bencana (BNPB) menunjuk Halodoc sebagai platform layanan kesehatan digital untuk tes cepat (rapid test) dan tes Polymerase Chain Reaction (PCR) virus COVID-19. Hal ini sangat membantu masyarakat untuk memenuhi kebutuhan tes deteksi COVID-19. Layanan tersebut dapat diperoleh dengan melakukan pembuatan janji terlebih dahulu via Halodoc. Pengguna aplikasi Halodoc ada yang kurang puas terhadap layanan yang ada pada aplikasi Halodoc seperti pelaksanaan tes yang tidak sesuai jadwal sehingga menimbulkan pembatalan, tidak tepatnya jadwal pemberian hasil tes, kesulitan dalam menemukan rujukan apotek untuk menebus obat serta customer service yang dinilai kurang responsif dan keluhan yang lainnya. Keluhan masyarakat ini dapat diketahui dari komentar yang ada pada kolom review aplikasi Halodoc. Karena jumlah pengguna yang menggunakan aplikasi meningkat, opini dari pengguna selama pandemi ini diperlukan untuk meningkatkan layanan pada aplikasi Halodoc. Oleh karena itu, perlu dilakukan analisis sentimen terhadap komentar yang ada pada layanan aplikasi tersebut.

Analisis sentimen adalah analisis pengolahan bahasa alami, komputasi linguistic, dan teks mining yang bertujuan menganalisis sentimen atau penilaian pada suatu produk atau layanan tertentu (Liu 2010). Text Mining merupakan proses penggalian atau penambangan data pada suatu teks yang bertujuan untuk mengetahui kata-kata yang dapat mewakili isi dari sebuah dokumen sehingga dapat dilakukan proses analisa lebih lanjut (Aggarwal 2018). Analisis sentimen dapat digunakan untuk melihat bagaimana kecenderungan suatu sentimen layanan aplikasi (Halodoc) baik yang negatif maupun positif. Proses klasifikasi teks review terhadap layanan telemedicine Halodoc untuk sentimen positif maupun negatif dilakukan dengan beberapa metode yang paling popular diantaranya Nä̈ve Bayes Classifier, KNN, SVM.

Penelitian mengenai Nä̈ve Bayes Classifier untuk melakukan klasifikasi pada aplikasi Halodoc telah dilakukan oleh Neng Resti Wardani (Wardani and Erfina 2021) yang memperoleh nilai akurasi 82,86 \%. merupakan metode klasifikasi dengan cara kerja menghitung probabilitas atau peluang berdasarkan rumus Bayesian Rule yang digunakan untuk memecahkan masalah klasifikasi pada feature - feature data bernilai nominal maupun numerik (Faisal and Nugrahadi 2017) dan dikenal memiliki tingkat akurasi tinggi pada pengaplikasian database dengan data yang besar (Prasetyo 2012). Berdasarkan penelitian Muhammad Rangga Aziz Nasution (Nasution and Hayaty 2019) diperoleh bahwa jika dibandingkan dengan KNN model SVM memiliki tingkat akurasi yang lebih baik

Oleh Karena itu, pada penelitian ini dilakukan perbandingan antara metode Nä̈ve Bayes Classifier dan Support Vector Machine pada analisis sentimen review pengguna layanan telemedicine Halodoc pada masa pandemi COVID-19 berdasarkan performa kinerja masing-masing algoritma. 


\section{METODE PENELITIAN}

\subsection{Sumber Data}

Data yang digunakan adalah data sekunder yaitu sekumpulan review atau ulasan dari para pengguna layanan telemedicine Halodoc (https://www.Halodoc.com). Data penelitian adalah data review Halodoc mulai tanggal 1 November 2020 sampai dengan 8 Februari 2021 dengan menggunakan metode scraping web.

\subsection{Variabel Penelitian}

Variabel penelitian dapat ditunjukkan pada Tabel 1 sebagai berikut.

Tabel 1 Variabel Penelitian

\begin{tabular}{clc}
\hline Variabel & \multicolumn{1}{c}{ Keterangan } & Skala data \\
\hline $\mathrm{X}$ & Jumlah kemunculan kata (Term Frequency) & Rasio \\
\hline & Kategori sentimen (Positif/Negatif) & \\
$\mathrm{Y}$ & $\begin{array}{l}\text { Syarat : Jika, skor } \geq 0 \text {, kategori positif } \\
\text { Jika, skor }<0 \text {, kategori negatif }\end{array}$ & Nominal \\
&
\end{tabular}

Adapun struktur data yang digunakan pada penelitian ini yang dapat ditunjukkan pada Tabel 2 sebagai berikut.

Tabel 2 Struktur Data

\begin{tabular}{ccc}
\hline No. & Jumlah kemunculan Term $(\mathrm{X})$ & $\begin{array}{c}\text { Kategori } \\
\text { Sentimen (Y) }\end{array}$ \\
\hline 1. & $\mathrm{X}_{1}$ & $\mathrm{Y}_{1}$ \\
2. & $\mathrm{X}_{2}$ & $\mathrm{Y}_{2}$ \\
$\vdots$ & $\vdots$ & $\vdots$ \\
$n$ & $\mathrm{X}_{n}$ & $\mathrm{Y}_{n}$ \\
\hline
\end{tabular}

Keterangan :

$\mathrm{X}_{i}$ : Jumlah kemunculan term

$\mathrm{Y}_{i}:$ Kategori sentimen (positif/ negatif)

dimana $i=1,2$ sampai dengan $\mathrm{n}$

\subsection{Metode Pengumpulan Data}

Data keseluruhan review yang terdapat di kolom review Halodoc sejak tahun 2016 sampai saat ini (update terakhir) adalah sebanyak 290.343 review. Scraping pengambilan data dimulai tanggal 1 November 2020 sampai dengan 8 Februari 2021 sehingga dihasilkan data review sebanyak 5.687 data. Pemberian label sentimen berdasarkan pada perhitungan skor dengan rumus sebagai berikut.

$$
S k o r=\left(Z_{k p}-Z_{k n}\right)
$$

Keterangan :

$Z_{k p}$ : Jumlah kata positif

$Z_{k n}$ : Jumlah kata negatif

\subsection{Langkah Penelitian}

Adapun metode analisis data yang digunakan berdasarkan tujuan penelitian adalah analisis sentimen dan perbandingan hasil performa ketepatan klasifikasi sentimen pengguna layanan telemedicine Halodoc. Analisis dilakukan dengan menggunakan bantuan software program R. Langkah-langkah pengolahan dan analisis data adalah sebagai berikut. 
1. Pemberian label sentimen review Halodoc

a. Perhitungan skor sentimen pada text review yang telah menjadi data bersih dengan menggunakan kamus lexicon.

b. Melakukan pemberian label sentimen review berdasarkan nilai skor. Jika nilai skor lebih besar daripada 0 maka dikategorikan positif sedangkan jika nilai skor lebih kecil dari 0 maka dikategorikan negatif.

\subsection{Pre-Processing Data}

a. Casefolding yaitu tahapan merubah semua huruf kapital menjadi huruf kecil yang terkandung didalam review text.

b. Cleaning yaitu tahapan menghapus tanda baca, angka, url dan karakter lain yang tidak diperlukan.

c. Spelling normalization yaitu memperbaiki pengejaan kata yang salah atau disingkat seperti kata 'sama' ditulis 'sm', kata 'aku' ditulis 'ak' dan sebagainya.

d. Stemming yaitu tahapan menghilangkan kata-kata imbuhan sehingga memperoleh kata dasar.

e. Tokenizing yaitu tahapan menguraikan review text menjadi kata per kata.

f. Stopwords yaitu tahapan menghilangkan kata-kata pada review text yang dianggap tidak penting dengan menggunakan stopwords yang telah dibuat.

g. Melakukan pembobotan dengan TF-IDF.

\subsection{Pengolahan dan Analisis Data}

1. Membagi data review yang telah diberi label atau kategori positif dan negatif menjadi data latih (training) dan data uji (testing) menggunakan $K$-fold cross validation. $K$-fold cross validation merupakan metode pembagian data antara data training dan data testing yang dilakukan untuk memvalidasi dataset agar menemukan nilai akurasi yang terbaik dengan cara membagi dataset sebanyak k subset (Mukharil,2017). Penggunaan 5-fold dengan proporsi antara data training dan testing dengan proporsi 80\%:20\%.

2. Klasifikasi data menggunakan pendekatan algoritma Nä̈ve Bayes Classifier.

3. Klasifikasi data menggunakan Support vector machine.

a. Membuat model SVM dengan menerapkan fungsi kernel

b. Melakukan optimasi parameter pada tiap jenis kernel

c. Memilih SVM kernel yang optimum

4. Melakukan evaluasi performa hasil klasfikasi.

Evaluasi yang dilakukan adalah dengan cara menghitung ketepatan klasifikasi dari metode Naïve Bayes Classifier dan Support vector machine yang berdasarkan pada tingkat Accuracy, Recall (Sensitivity), dan Specitivity jika data balanced sedangkan jika data imbalanced menggunakan AUC dan G-Mean.

5. Membuat visualisasi review melalui wordcloud.

7.Menginterpretasikan hasil analisis

\subsection{Support Vector Machine}

Support vector machine adalah metode prediksi dalam permasalahan klasifikasi dan regresi (Santosa 2007). Prinsip dasar Support vector machine pada permasalahan klasfikasi yang secara linear maupun non linear dengan memasukkan konsep kernel pada ruang kerja yang berdimensi tinggi dengan cara kerja memisahkan kedua class atau kelompok suatu data dengan adanya garis hyperlane optimal yang tujuannya untuk mencari hyperlane terbaik (Faisal and Nugrahadi 2017). Penggunaan Support vector machine untuk klasifikasi karena SVM mempunyai keunggulan dalam menggeneralisasi data jika dibandingkan dengan teknik sebelumnya (Vapnik et al. 1997). Adapun jenis kernel yang digunakan yaitu Kernel RBF sebagai berikut. 


$$
K\left(\mathbf{x}_{i}, \mathbf{x}_{j}\right)=\exp \left(-\gamma\left\|\mathbf{x}_{i}, \mathbf{x}_{j}\right\|^{2}\right), \gamma>0
$$

\subsection{Ketepatan Klasifikasi}

Salah satu pengukuran performa klasifikasi dengan menggunakan tabulasi silang atau confusion matrix (Prasetyo 2012) yang dapat menunjukkan klasifikasi berdasarkan data aktual terhadap data hasil prediksi dari model yang terbentuk yang ditunjukkan pada Tabel 3.

Tabel 3 Confusion Matrix Klasifikasi Dua Kelas

\begin{tabular}{cccc}
\hline & \multicolumn{2}{c}{ Hasil prediksi } \\
\cline { 3 - 4 } Aktual & Positif & \multicolumn{1}{c}{ Negatif } \\
\hline \multirow{2}{*}{ Positif } & True positive (TP) & False Positive (FP) \\
& Negatif & False Negative (FN) & True Negative (TN) \\
\hline
\end{tabular}

\subsection{Wordcloud}

Wordcloud adalah salah satu metode analisis dalam Text Mining yang dapat memberi visualisasi data teks yang menggambarkan frekuensi kata- kata yang ditampilkan dalam bentuk yang menarik namun informatif. Semakin besar ukuran kata pada tampilan wordcloud maka semakin sering kata tersebut digunakan (Fellows 2012).

\section{HASIL DAN PEMBAHASAN}

\subsection{Karakteristik Data}

Karakteristik data hasil review pengguna layanan telemedicine Halodoc berdasarkan hasil pemberian label sentimen kategori negatif dan positif menunjukkan bahwa persentase jumlah sentimen review pengguna layanan telemedicine Halodoc kategori negatif sebesar 12,33\% sedangkan sentimen kategori positif adalah 87,67\% dari 5.687 review. Hal tersebut menunjukkan bahwa data review dapat dikatakan imbalance karena jumlah kategori review kategori positif dan negatif tidak seimbang sehingga pengukuran ketepatan klasifikasi data review pengguna layanan telemedicine Halodoc menggunakan G-Mean dan AUC.

Tabel 4 Contoh Hasil Pra-proses Data

\begin{tabular}{ll}
\hline \multicolumn{1}{c}{ Proses } & \multicolumn{1}{c}{ Review } \\
\hline Review awal & Pelayanan yang baik dan cepat tanggapnya.Terima kasih holodokter \\
Case folding & pelayanan yang baik dan cepat tanggapnya terimakasih halodokter \\
Cleaning & pelayanan yang baik dan cepat tanggapnya terimakasih holodokter \\
Spelling & pelayanan yang baik dan cepat tanggapnya terimakasih halodoc \\
Normalization & "layan", "yang", "baik", "dan", "cepat", "tanggap", "terimakasih", \\
Stemming & "halodoc" \\
Tokenizing & "layan", "yang", "baik", "dan", "cepat", "tanggap", "terimakasih", \\
Stopwords & "halodoc" \\
\hline
\end{tabular}

\subsection{Naïve Bayes Classifier}

Nä̈ve Bayes Classifier merupakan salah satu metode klasifikasi dengan menggunakan probabilitas untuk mengklasifikasikan review tersebut kedalam kategori sentimen positif maupun negatif. Adapun pembagian data menjadi sebanyak $k$-fold cross validation maka akan dilakukan beberapa percobaan sebanyak 5-fold cross validation untuk memperoleh model yang memberikan hasil optimum. Fold yang terpilih yaitu k-1. 
Pengukuran performa klasifikasi Nä̈ve Bayes Classfier dalam klasifikasi sentimen review positif dan negatif yang ditunjukkan pada Tabel 5 .

Tabel 5 Hasil Ketepatan Klasifikasi Nä̈ve Bayes Classfiier

\begin{tabular}{cccc}
\hline$k$-fold & Akurasi & AUC & $G$-Mean \\
\hline k-1 & 0.8777 & 0.5711 & 0.4008 \\
\hline
\end{tabular}

Tabel 5 menunjukkan bahwa performa model yang terbentuk pada fold k-1 diperoleh nilai Area Under Curve (AUC) sebesar 0.5711 dan nilai G-Mean sebesar 0.4008. Hasil ketepatan klasifikasi review kategori sentimen positif dan negatif sehingga hasil ketepatan klasifikasi sentimen dapat dibentuk melalui confusion matrix yang ditunjukkan pada Tabel 6.

Tabel 6 Confusion Matrix Nä̈ve Bayes Classfier

\begin{tabular}{cccc}
\hline \multirow{2}{*}{ Prediksi } & \multicolumn{2}{c}{ Aktual } & \multirow{2}{*}{ Jumlah observasi } \\
\cline { 2 - 3 } & Positif & Negatif & \\
\hline Positif & 975 & 117 & 1092 \\
Negatif & 22 & 23 & 45 \\
\hline Jumlah observasi & 997 & 140 & 1137
\end{tabular}

Tabel 6 menunjukkan bahwa algoritma nä̈ve bayes classifier memberikan prediksi review sentimen kategori positif sebanyak 1092 dan dapat mengklasifikasikan secara benar sebanyak 975 review sedangkan yang terklasifikasi salah sebanyak 117 review. Hasil prediksi review sentimen kategori negatif sebanyak 45 review dapat diklasifikasi secara benar sebanyak 23 sedangkan yang diklasifikasi salah sebanyak 22 review.

\subsection{Support Vector Machine}

Support Vector Machine memiliki konsep mencari hyperplane terbaik yang dijadikan sebagai pemisah dua kelas data dengan cara memaksimalkan margin pemisah. Adapun kernel trik yang mampu diterapkan pada data berdimensi tinggi. Kernel yang digunakan pada penelitian ini yaitu Radial Basis Function $(R B F)$. Adapun penggunaan pembagian data pada SVM menggunakan 5-fold cross validation untuk memperoleh model yang memberikan hasil optimum.

SVM radial basis function ( $R B F$ ) fungsi Gaussian dengan menggunakan parameter . Adapun parameter yang digunakan yaitu $C$ menunjukkan jarak margin optimasi untuk menghindari kesalahan klasifikasi SVM dan gamma $(\gamma)$ menunjukkan percepatan fungsi pada kernel $R B F$ agar mendapatkan akurasi dari model klasifikasi yang optimal. parameter $C$ dan gamma SVM Kernel $R B F$ yang optimum adalah parameter $C=1000$ dan Gamma=0.1 Pengukuran performa klasifikasi Support Vector Machine dalam klasifikasi sentimen review positif dan negatif yang ditunjukkan pada Tabel 7.

Tabel 7 Hasil Ketepatan Klasifikasi SVM Kernel $R B F$

\begin{tabular}{cccc}
\hline$k$-fold & Akurasi & AUC & G-Mean \\
\hline $\mathrm{k}-1$ & 0.861 & 0.60149 & 0.49311 \\
\hline
\end{tabular}

Tabel 7 menunjukkan bahwa klasifikasi menggunakan SVM kernel $R B F$ yang terbaik dengan nilai parameter $\mathrm{C}=1000$ dan gamma $=0,1$ pada fold $\mathrm{k}-2$ menghasilkan nilai AUC sebesar 0.5531308 dan G-Mean sebesar 0.3367 sehingga hasil ketepatan klasifikasi sentimen dapat dibentuk melalui confusion matrix yang ditujukkan pada Tabel 8 . 
Tabel 8 Confusion Matrix SVM RBF

\begin{tabular}{cccc}
\hline \multirow{2}{*}{ Prediksi } & \multicolumn{2}{c}{ Aktual } & \multirow{2}{*}{ Jumlah observasi } \\
\cline { 2 - 3 } & Positif & Negatif & \\
\hline Positif & 943 & 104 & 1047 \\
Negatif & 54 & 36 & 90 \\
\hline Jumlah observasi & 997 & 140 & 1137 \\
\hline
\end{tabular}

Tabel 8 menunjukkan bahwa algoritma Support Vector Machine Kernel RBF memberikan prediksi review sentimen kategori positif sebanyak 1047 dan dapat mengklasifikasikan secara benar sebanyak 943 review sedangkan yang terklasifikasi salah sebanyak 104 review. Hasil prediksi review sentimen kategori negatif 90 review dapat terklaisifikasi secara benar sebanyak 36 sedangkan yang terklasifikasi salah sebanyak 54 review.

\subsection{Perbandingan Hasil Klasifikasi Algoritma Nä̈ve Bayes Classifier dan Support Vector Machine}

Perbandingan hasil ketepatan klasifikasi antara kedua Algoritma Nä̈ve Bayes Classifier dan Support Vector Machine dapat ditunjukkan pada Tabel 9.

\begin{tabular}{cccc}
\multicolumn{4}{c}{ Tabel 9 Hasil Perbandingan Algoritma NBC dan SVM } \\
\hline Algoritma & Akurasi & AUC & G-Mean \\
\hline NBC & 0.8777 & 0.5711 & 0.4008 \\
SVM Kernel RBF & $\mathbf{0 . 8 6 1}$ & $\mathbf{0 . 6 0 1 4 9}$ & $\mathbf{0 . 4 9 3 1 1}$ \\
\hline
\end{tabular}

Tabel 9 menunjukkan bahwa Algoritma NBC memiliki nilai akurasi sebesar 0.8777, AUC sebesar 0.5711 dan G-Mean sebesar 0.4008 sedangkan Algoritma SVM Kernel RBF memiliki nilai akurasi sebesar 0.861, AUC sebesar 0.60149 dan nilai G-Mean sebesar 0.49311 yang artinya berdasarkan nilai akurasi, AUC dan G-Mean SVM Kernel RBF lebih baik daripada NBC pada pengklasifikasian review sentimen pengguna layanan telemedicine Halodoc.

\subsection{Visualisasi Wordcloud}

Visualisasi wordcloud dapat memberikan informasi mengenai kata-kata apa yang sering muncul pada data review pengguna layanan telemedicine Halodoc sesuai dengan kategori sentimennya. Frekuensi kemunculan kata-kata yang sering muncul berdasarkan ukuran font yang terbentuk. Semakin besar ukurannya maka kata tersebut sering muncul yang dapat ditunjukkan pada Gambar 1 dan Gambar 2 sebagai berikut.

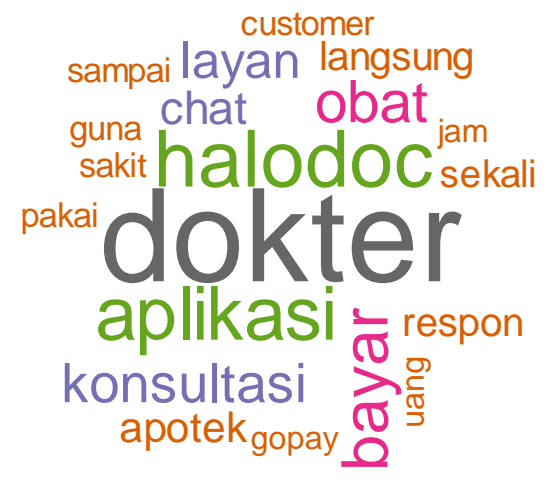

Gambar 1 Wordcloud Sentimen Negatif

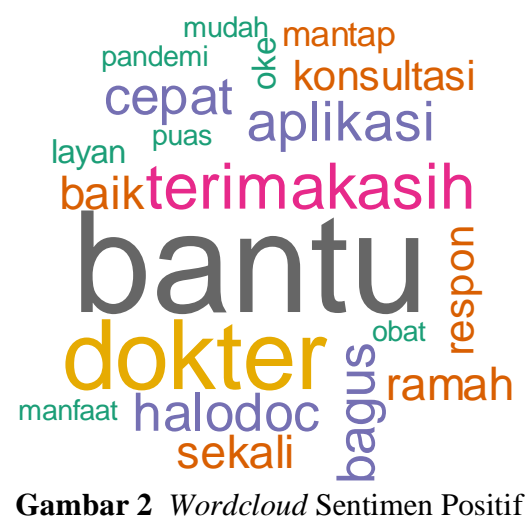

Gambar 2 Wordcloud Sentimen Positif

Gambar 1 menunjukkan bahwa kata-kata sentimen kategori negatif yang sering muncul adalah Kata "dokter" karena menurut beberapa pengguna terdapat dokter yang 
kurang informatif dalam menjawab pertanyaan pengguna. Kata "bayar" beberapa pengguna mengeluhkan sistem pembayaran Halodoc. Kemudian Kata "apotek" karena beberapa pengguna merasa layanan apotek Halodoc kurang lengkap dan kata "customer service" yang dirasa beberpa pengguna kurang responsive dalam menangani masalah pengguna.sehingga diharapkan customer service lebih responsif dalam membantu menangani masalah para pengguna layanan telemedicine Halodoc.

Gambar 2 menunjukkan bahwa kata-kata sentimen kategori positif yang sering muncul adalah kata "bantu" karena pengguna merasa sangat terbantu dengan layanan aplikasi Halodoc terutama di masa pandemi dan praktis melalui online. Kemudian kata "dokter", "cepat", "ramah" dan respon" karena pengguna merasa dokter Halodoc dapat melayani dengan respon cepat dan ramah.

\section{KESIMPULAN}

Berdasarkan hasil analisis dan pembahasan dapat diperoleh kesimpulan bahwa persentase jumlah sentimen review pengguna layanan telemedicine Halodoc kategori negatif sebesar 12,33\% sedangkan sentimen kategori positif adalah 87,67\% dari 5.687 review.yang artinya jumlah review kategori positif lebih banyak daripada kategori negatif. Performa ketepatan klasifikasi Algoritma NBC memiliki nilai akurasi sebesar 0.8777, AUC sebesar 0.5711 dan G-Mean sebesar 0.4008 sedangkan Algoritma SVM Kernel RBF memiliki nilai akurasi sebesar 0.861, AUC sebesar 0.60149 dan nilai G-Mean sebesar 0.49311 yang artinya berdasarkan nilai akurasi, AUC dan G-Mean SVM Kernel $R B F$ lebih baik daripada NBC pada pengklasifikasian review sentimen pengguna layanan telemedicine Halodoc. Kata-kata sentimen kategori negatif yang sering muncul adalah "bayar", "apotek" dan "customer service" sedangkan Kata-kata sentimen kategori positif yang sering muncul adalah "dokter" "bantu" "ramah", "cepat", "aplikasi”, "obat" dan "konsultasi”.

\section{DAFTAR PUSTAKA}

Aggarwal, C. C. (2018), Machine learning for text, Machine Learning for Text. https://doi.org/10.1007/978-3-319-73531-3.

Coelho, K. R. (2011), "Identifying Telemedicine Services to Improve Access to Specialty Care for the Underserved in the San Francisco Safety Net," International Journal of Telemedicine and Applications, 2011, 1-14. https://doi.org/10.1155/2011/523161.

Faisal, M. R., and Nugrahadi, D. T. (2017), Belajar Data Science: Klasifikasi dengan Bahasa Pemrograman R, Kalimantan Selatan: Scripta Cendekia.

Fellows, I. (2012), "Wordcloud: Word clouds," R package version.

Fitri, A. (2020), "Selama pandemi covid-19, instalasi Halodoc meningkat 10 kali lipat," Kontan, Available athttps://kesehatan.kontan.co.id/news/selama-pandemi-covid-19instalasi-halodoc-meningkat-10-kali-lipat.

Liu, B. (2010), "Sentiment Analysis and Subjectivity in: Handbook of Natural Language Processing, Second Edition," Handbook of Natural Language Processing, Second Edition, 2.

Nasution, M. R. A., and Hayaty, M. (2019), "Perbandingan Akurasi dan Waktu Proses Algoritma K-NN dan SVM dalam Analisis Sentimen Twitter," Jurnal Informatika, 6, 226-235. https://doi.org/10.31311/ji.v6i2.5129.

Prasetyo, E. (2012), Data Mining: konsep dan aplikasi menggunakan MATLAB, Yogyakarta: Andi.

Santosa, B. (2007), Data Mining Teknik Pemanfaatan Data untuk Keperluan Bisnis, Yogyakarta: Graha Ilmu.

Vapnik, V., Golowich, S. E., and Smola, A. (1997), "Support vector method for function 
approximation, regression estimation, and signal processing," in Advances in Neural Information Processing Systems.

Wardani, N. R., and Erfina, A. (2021), “Analisis Sentimen Masyarakat Terhadap Layanan Konsultasi Dokter Menggunakan Algoritma Naive Bayes," in Seminar Nasional Sistem Informasi dan Manajemen Informatika, Universitas Nusa Putra, pp. 11-18. 